\title{
Entrepreneurship Development as a Strategy for Poverty Alleviation among Farming Households in Igbo-Eze North Local Government Area of Enugu State, Nigeria
}

\author{
Mbam B. N. and *Nwibo S. U. \\ Department of Agricultural Economics, Management and Extension, Ebonyi State University, \\ Abakaliki.
}

ARTICLE INFO

Article No.: 100613883

DOI: 10.15580/GJAS.2013.10.100613883

Submitted: 10/06/2013

Accepted: 22/10/2013

Published: 29/10/2013

*Corresponding Author

Nwibo S. U.

E-mail: sunwibo92@yahoo.com

Keywords:

entrepreneurship, development, strategy, poverty alleviation, farming households
The emergence of the free market economies globally, has resulted in the development of a new spirit of enterprise and the increased farmer's need for more responsibility in running their farm business. Multistage random sampling technique was used to select a total of 120 respondents used for the study. Primary data were collected using structured questionnaires. Both descriptive and inferential statistics was used to achieve the objectives of the study. Results showed that the farmers are within the average productive age of 44 years and an average household size of 6 persons. Meanwhile, despite the participation of the farming households in entrepreneurial activities, its development has not been fully embraced. Hence, at $0.05(P=0.05)$ level of significance of entrepreneurial development has not contributed much in reducing poverty among the farming household in the area. The development and acquisition of entrepreneurship skills among the farmers were constrained by inadequate market opportunities, poor access to credit facility, inadequate market information, poor managerial skills, inadequate power supply, high taxation, and poor government policies on entrepreneurial development. Despite the problems confronting the development of entrepreneurship among the farming households, the study concluded that entrepreneurial development has contributed in poverty reduction in the area. The study however, recommended adequate entrepreneurship development programmes for farmers while addressing factors that hinder its growth and development as a way of actualising the current transformation agenda of the present federal government of Nigeria on poverty eradication through farming activities. 


\section{INTRODUCTION}

It has been reported by World Bank in 1996 that poverty in Nigeria is becoming widespread and severe (Kudi, et al.) and in spite of the Nigeria's vast resources, the country is known for her low Gross Domestic Product (GDP), low per capital income, high unemployment rate, low industrial utilization capacity, high birth rate and subsistence agricultural dependent. According to Ocar (2003), Nigeria ranks number $148^{\text {th }}$ in 2002 according to Human Development Index rating. It was further reported that the Nigeria's basic indicators placed the country among the 26 poorest countries in the world.

The proportion of Nigerians living below the poverty line of one dollar a day has increased dramatically during the last two decades. In the year 2000 , more than $70 \%$ of Nigerians were estimated to be living below the internationally defined poverty line (Ocar, 2003). Furthermore, in the same year, both per capita income and per capita private consumption were lower than that obtained in the early 1970s. Per capita income fell from $\$ 1,600$ in 1980 to $\$ 270$ in 2000 and the trend continued till date. Generally, about 90 percent of Nigeria's poor are engaged in agriculture, while 58 percent of the urban population is living in poverty (Ogunlela and Ogungbile, 2006). However, successive governments in Nigeria have introduced various poverty reduction programmes. These programmes include the Family Economic Advancement Programme (FEAP), Structural Adjustment Programme (SAP), Green Revolution Programme (GRP), Directorate for Food, Road and Rural Infrastructure (DFRRI) and most recently, the National Poverty Eradication Programme (NAPEP) that recorded marginal impact on poverty, despite large budgetary allocations. These programmes failed to achieve their objectives because of poor design and based on this, the Federal Government of Nigeria initiated a new poverty reduction plan based on lessons learnt from the past, aimed at reducing the level of poverty from 70 percent to 35 percent by 2015 .

It was in realization of the forgoing scenario that the Federal Government of Nigeria announced the inclusion of entrepreneurship education in higher institutions of learning, as a way of promoting entrepreneurship spirit among Nigerian youths to takeup self-employment especially in the agricultural sector. This has led to the launching of programmes such as Youth Enterprise with Innovation in Nigeria (YouWiN) which is an innovative business plan competition aimed at job creation by encouraging and supporting aspiring entrepreneurial youths in Nigeria to develop and execute business ideas (YouWiN, 2012). The programme is being funded and implemented in partnership with Nigeria's private sector. It is aimed at empowering the resource poor farmer especially in the rural areas to take responsibility for their businesses and theoretically, have more freedom to farm as they wish (European Commission, 2004). This is because entrepreneurial development in rural areas has been connected with a progressive modernization of agriculture and is connected with multifunctional rural development (Zmija, 2001).
Nowadays, especially after the adoption of new economic policy, entrepreneurship has assumed a more significant role in the economic development of Nigeria. For instance, under the impact of rapidly changing business environment, the role of entrepreneurship extends beyond increasing per capita output and income. It is increasingly expected to work as catalytic force for economic development and because of entrepreneurship development, rapid changes and progress across wide range of industries has taken place throughout the world.

Thus, farmers are becoming more entrepreneurial in developing new skills and functional capabilities in order to be competitive as the development of entrepreneurship means also a change in quality of management in the process of farming (Firlej, 2001).

However, despite the potential of agriculture in the Nigerian economy, poverty and hunger have remained serious threats and obstacle to the development of the entire country (Mbam et.al., 2010). Thus, with the exceptions of few cases, the role of entrepreneurship and innovation has been given little emphasis in agriculture in spite of the fact that it is a critical aspect of value-added agriculture (Knudson et al., 2004). Indeed, this literature search identifies only a small number of articles that attempt to define farm entrepreneurship and only several, which attempt to apply literature from other sectors to the farm sector. Some studies have dealt with entrepreneurship in the business activities related to processing and marketing of the farm products (Warren, 2004), but the primary production on farms has been largely invisible. It is against this seemly dearth of empirical literature on entrepreneurship development among farmers that the study was undertaken in order to fill this gap in knowledge that existed on the subject under review. Meanwhile, in doing justice to this research work, the following research objectives were formulated and addressed: describing of the socio-economic characteristics of the farmers in the area; analyzing the various entrepreneurship activities of the farmers in the area; analyzing the extents to which entrepreneurship activities have reduced poverty in the area; and lastly identifying the constraints that militated against entrepreneurship development in the study area.

\section{METHODOLOGY}

The study was carried out in Igbo-Eze North Local Government Area (L.G.A) of Enugu State. The L.G.A is made up of four communities. It is bounded in the North by Egule Local Government Area of Kogi State, in the South by Igbo-Eze South Local Government Area, in the East by Udenu Local Government Area, and in West by Akpanya Local Government Area of Kogi State. It has a total population of 178,964 people (NPC, 2006). The L.G.A is located within latitudes $5^{0} 53^{\prime} \mathrm{N}$ to $5^{0} 24^{\prime} \mathrm{N}$ of equator and longitudes $9^{0} 56^{\prime} \mathrm{E}$ to $9^{0} 26^{\prime} \mathrm{E}$ of Greenwich meridian.

The area is influenced by two main type of wind, namely: the South-west and North-east trade wind. 
These winds types gave rise to two different seasons the rainy and dry seasons. The rainy season begins in March and ends in October while the dry season prevails from November to February. The major staple crops grown by the people are; cassava, yams, cocoyam, groundnut. They also produce Cash crops such as cashew, oranges, banana, plantain, mango and oil palm and vegetables such as okra, melon, water leaf, Telfalia occidentalis (Ugu).

\section{RESULTS AND DISCUSSION}

\section{Socio-economic Characteristics of the Respondents}

Table 1: Distribution of the respondents according to socio-economic characteristics

\begin{tabular}{|c|c|c|c|c|}
\hline Variables & Description & uency $(n=120)$ & Percentage & $\overline{\mathbf{x}}$ \\
\hline \multirow[t]{4}{*}{ Age (years) } & $21-30$ & 15 & 12.5 & $\overline{44}$ \\
\hline & $31-40$ & 21 & 17.5 & \\
\hline & $41-50$ & 50 & 41.7 & \\
\hline & $51-60$ & 34 & 28.3 & \\
\hline \multirow[t]{2}{*}{ Gender } & Male & 68 & 56.7 & \\
\hline & Female & 52 & 43.3 & \\
\hline \multirow[t]{3}{*}{ Marital status } & Single & 34 & 28.3 & \\
\hline & Married & 77 & 64.2 & \\
\hline & Widowed & 9 & 7.5 & \\
\hline \multirow[t]{4}{*}{ Household size } & $1-4$ & 40 & 33.3 & 6 \\
\hline & $5-8$ & 65 & 54.2 & \\
\hline & $9-12$ & 11 & 9.2 & \\
\hline & $13-16$ & 4 & 3.3 & \\
\hline \multirow[t]{5}{*}{ Educational level } & No formal education & 22 & 18.3 & \\
\hline & Primary & 26 & 21.7 & \\
\hline & Secondary & 42 & 35.0 & \\
\hline & OND/NCE & 19 & 15.8 & \\
\hline & HND/B.Sc. & 11 & 9.2 & \\
\hline \multirow[t]{4}{*}{ Farming experience } & $6-10$ & 13 & 10.8 & 16 \\
\hline & $11-15$ & 48 & 40.0 & \\
\hline & $16-20$ & 41 & 34.2 & \\
\hline & $21 \&$ above & 18 & 15.0 & \\
\hline \multirow[t]{6}{*}{ Annual farm income } & $\leq 50,000$ & 16 & 13.3 & 162,430 \\
\hline & $50,001-100,000$ & 19 & 15.8 & \\
\hline & $100,001-150,000$ & 26 & 21.7 & \\
\hline & $150,001-200,000$ & 34 & 28.3 & \\
\hline & $200,001-250,000$ & 18 & 15.0 & \\
\hline & $300,001-350,000$ & 7 & 5.8 & \\
\hline \multirow{8}{*}{ Total annual income } & $\leq 50,000$ & 2 & 1.7 & 223,483 \\
\hline & $50,001-100,000$ & 3 & 2.5 & \\
\hline & $100,001-150,000$ & 18 & 15 & \\
\hline & $150,001-200,000$ & 35 & 29.2 & \\
\hline & $200,001-250,000$ & 21 & 17.5 & \\
\hline & $250,001-300,000$ & 26 & 21.7 & \\
\hline & $300,001-350,000$ & 6 & 5 & \\
\hline & $350,001 \&$ above & 9 & 7.5 & \\
\hline \multirow[t]{3}{*}{ Farm size } & $3-5$ & 42 & 35 & 6 \\
\hline & $6-8$ & 60 & 50 & \\
\hline & 9 and above & 18 & 15 & \\
\hline
\end{tabular}

Source: Field Survey, 2012

Result of the analysis as presented in Table 1showed that the farmers are within the average age of 44 years. The age distribution of the farmers showed that they
A multistage random sampling technique was used in selecting the respondents for the study. Data were collected mainly from primary source using structured questionnaire that was administered to the 120 randomly selected respondents. Both descriptive and inferential statistics were used in analyzing the data. Descriptive statistics such as mean, frequency tables, percentages, were used in analyzing objective $\mathrm{i}$, and ii, while objective iii and iv were analyzed using mean score derived from 4-point Likert scale. 
43 years for the agribusiness investors in Southeast Nigeria. Gender analysis of the farmers showed that more than half $(56.7 \%)$ of the respondents were males while $43.3 \%$ of them were females. This can be attributed to the traditional right of dominance the males have over females on issues like land acquisition and other production factors. It was also observed that most $(64.2 \%)$ of the respondents were married with an average household size of 6 persons. This implied that the farmers who were engaged in farming enterprises in the area have a relatively large household size that formed bulk of the farm labour demand of the households. Also, most (35.0\%) of the respondents completed secondary school education (higher school) which signified that the farmers have adequate educational background that is relevant for adoption of innovations in agriculture. Again, the result showed that the farmers earned an average annual farm income of $\mathrm{N} 162,430.00$ and total annual income of N223, 480.00. The result implied that the farmers are low income earners; however, most of the farmers may have diversified into non-farming sector which has resulted in mean income difference of N61, 050 that was recorded. Finally, it was also found that the farmers who had an average size of 6 hectares had been in farming activities for an average of 6 years.

\section{Entrepreneurial Activities of the Farmers}

Agribusiness entrepreneurial activities can be categorised into farm input supply, farm production, agro-processing, and distribution (Nwibo and Okorie, 2013). From the analysis (Table 2), it was noted that under farm input supply category, $40 \%$ of the farmers are into seed/seedling supply while $15 \%$ are into supply of breeding stock. In the farm production, it was observed that $80 \%$ of the farmers are into arable crops production such as cassava, yam and rice, while $17.5 \%$ of them are into livestock productions such as goat/sheep and poultry and $2.5 \%$ of them are into fisheries production. Based on the responses of the respondents, the agro-processing activities carried by them are cassava processing (40\%), leguminous and nut processing especially cashew nut $(25 \%)$, palm oil processing $(20 \%)$, rice processing $(12.5 \%)$ and $(2.5 \%)$ of the farmers are into wood lumbering. The farm marketing and distribution activities of the farmers showed that $42.5 \%$ are into cassava products marketing, $20 \%$ are into palm products marketing and distribution, $17.5 \%$ market and distribute rice, while $12.5 \%$ are into yam marketing and $2.5 \%$ of them are into timber products marketing and distribution in the area.

Table 2: Distribution of the respondents according to entrepreneurship activities existing in the area

\begin{tabular}{|c|c|c|}
\hline $\begin{array}{l}\text { Categories of } \\
\text { Activities }\end{array}$ & Areas of Activities & $\begin{array}{l}\text { Frequency } \\
(n=120)\end{array}$ \\
\hline \multirow[t]{7}{*}{ Farm input supply } & Farm equipment & - \\
\hline & Fertilizer & - \\
\hline & Agro-chemicals & - \\
\hline & Seedlings & $48(40)$ \\
\hline & Livestock feeds & - \\
\hline & Breeding stocks & 18(15) \\
\hline & Medical and drugs supplies & - \\
\hline \multirow[t]{3}{*}{ Farm production } & $\begin{array}{l}\text { Arable crop production (e.g. cassava, rice, yam } \\
\text { etc) }\end{array}$ & $96(80)$ \\
\hline & $\begin{array}{l}\text { Livestock production (e.g. poultry, piggery, } \\
\text { goat/sheep etc) }\end{array}$ & $21(17.5)$ \\
\hline & Aquaculture (fisheries) production & $3(2.5)$ \\
\hline \multirow[t]{6}{*}{ Agro processing } & Cassava processing & $48(40)$ \\
\hline & Livestock feed processing & - \\
\hline & Palm oil processing & $24(20)$ \\
\hline & Rice processing & 15(12.5) \\
\hline & Wood lumbering (Timber work) & $3(2.5)$ \\
\hline & Leguminous \& nuts processing & $30(25)$ \\
\hline \multirow[t]{8}{*}{ Farm distribution/ marketing } & Cassava products & $51(42.5)$ \\
\hline & Flour & - \\
\hline & Confectionaries & $6(5)$ \\
\hline & Palm products & $24(20)$ \\
\hline & Timber products & $3(2.5)$ \\
\hline & Livestock feeds & - \\
\hline & Rice & $21(17.5)$ \\
\hline & Yam & $15(12.5)$ \\
\hline \multirow[t]{4}{*}{ Non-farm activities } & Artisan & $39(32.5)$ \\
\hline & Trading & $33(27.5)$ \\
\hline & Agro-tourism & $18(15)$ \\
\hline & Civil service & $30(25)$ \\
\hline
\end{tabular}

Source: Field Survey, 2012 
From the non-farm activities of farmers, the result showed that $32.5 \%$ of them are into artisan fishery, $27.5 \%$ are into trading, while $25 \%$ are into civil service and $15 \%$ of them are into agro-tourism. The finding implied that the farmers engage into various farm and non-farm entrepreneurship activities as a way of income diversification which helps in reducing poverty among the farming households. This finding is in consonance with Lwakuba (2011) who reported the farm production paradigms in Uganda have emphasized options that include intensifying conventional production by volume increase as well as by selective and well managed specialization and diversification. These options include engagement in different agricultural operations such as food processing, direct marketing or organic production among others as well as engagement in business activities or involvement in the provision of (agriculture support) services such as the handling of agricultural inputs including certified seed, fish fry or breeding improved animals. Again, Vesala and Peura (2003) inferred in a study commissioned by European Union that farmer who do not diversify lack entrepreneurial skills, growth and expansion of farm business.

\section{Poverty Reduction through Entrepreneurship}

Entrepreneurship has been hypothesised to have significant effect in reducing poverty among farming households. Individual assessment of the five categories of entrepreneurial activities as adopted in this study (Table 3) showed that under the input supply category, the supply of seeds and seedlings (2.5) has impacted positively towards poverty reduction among the farmers. In the farm production category, the study revealed that arable crops (3.8) and livestock productions (3.0) respectively have been effective in reducing poverty among the farmers. From the agro processing category, cassava processing (3.5), palm oil processing (3.2), rice processing (2.7) and leguminous and nut processing (2.8) have positive impact on the poverty reduction among the farmers. In the farm distribution/marketing category, marketing and distributions of cassava products (3.4), palm oil products (2.9), rice (2.8), and yam (2.8) were accepted by the farmers as having impacted on poverty reduction. While from the non-farm sector, artisanal activities (3.5), trading (3.2) and civil service (2.8) were also accepted as having reduced poverty among the farmers in the area.

Table 3: Distribution of the Respondents according to the extent to which entrepreneurship activities have reduced poverty in the area

\begin{tabular}{|c|c|c|c|c|}
\hline $\begin{array}{l}\text { Categories of } \\
\text { Entrepreneuri } \\
\text { al Activities }\end{array}$ & Areas of Activities & $\begin{array}{l}\text { Freq. } \\
(N=120)\end{array}$ & $\begin{array}{l}\text { Mean } \\
\text { score }\end{array}$ & Decision \\
\hline \multirow[t]{7}{*}{ Farm input supply } & Farm equipment & - & & \\
\hline & Fertilizer & - & & \\
\hline & Agro-chemicals & - & & \\
\hline & Seedlings & $48(40)$ & 2.5 & Accepted \\
\hline & Livestock feeds & & & \\
\hline & Breeding stocks & $18(15)$ & 2.2 & Rejected \\
\hline & Medical and drugs supplies & & & \\
\hline \multirow[t]{3}{*}{ Farm production } & $\begin{array}{l}\text { Arable crop production (e.g. cassava, rice, yam } \\
\text { etc) }\end{array}$ & $96(80)$ & 3.8 & Accepted \\
\hline & $\begin{array}{l}\text { Livestock production (e.g. poultry, piggery, } \\
\text { goat/sheep etc) }\end{array}$ & $21(17.5)$ & 3.0 & Accepted \\
\hline & Aquaculture (fisheries) production & $3(2.5)$ & 2.2 & Rejected \\
\hline \multirow[t]{6}{*}{ Agro processing } & Cassava processing & $48(40)$ & 3.5 & Accepted \\
\hline & Livestock feed processing & - & & \\
\hline & Palm oil processing & $24(20)$ & 3.2 & Accepted \\
\hline & Rice processing & $15(12.5)$ & 2.7 & Accepted \\
\hline & Timber & $2(2.5)$ & 1.6 & Rejected \\
\hline & Leguminous \& nuts processing & $30(25)$ & 2.8 & Accepted \\
\hline \multirow[t]{7}{*}{$\begin{array}{l}\text { Farm distribution/ } \\
\text { marketing }\end{array}$} & $\begin{array}{l}\text { Cassava products } \\
\text { Flour }\end{array}$ & $51(42.5)$ & 3.4 & Accepted \\
\hline & Confectionaries & $6(5)$ & 1.5 & Rejected \\
\hline & Palm products & $24(20)$ & 2.9 & Accepted \\
\hline & Timber products & $3(2.5)$ & 1.8 & Rejected \\
\hline & Livestock feeds & - & & \\
\hline & Rice & $21(17.5)$ & 2.8 & Accepted \\
\hline & Yam & $15(12.5)$ & 2.6 & Accepted \\
\hline \multirow[t]{4}{*}{ Non-farm activities } & Artisan & $39(32.5)$ & 3.5 & Accepted \\
\hline & Trading & $33(27.5)$ & 3.2 & Accepted \\
\hline & Agro-tourism & $18(15)$ & 2.1 & Rejected \\
\hline & Civil service & $30(25)$ & 2.8 & Accepted \\
\hline
\end{tabular}

Source: Field Survey, 2012

The study impliedly showed that if farming households should actively participation in non-farm activities, farm production, farm processing and farm distribution/marketing, poverty will be adequately reduced in the area. Comparatively, the farm input supply component of agribusiness has not contributed 
much towards poverty reduction among the farmers. Though, individual assessment of the entrepreneurial activities in the area showed significant contribution to the reduction of poverty, the overall assessment showed that at $0.05(P=0.05)$ level of significance, entrepreneurship has not contributed much in reducing poverty among the farming household in the area. This can be attributed to the low income level of the farmers which do not allow for expansion of the existing enterprises which will consequently lead to poverty reduction and improvement of standard of living among the farmers.

\section{Constraints Militating Against Entrepreneurship Development}

Table 4: Mean Score Distribution of the Respondents Based on Constraints to Entrepreneurship Development of the Farmers in the Area

\begin{tabular}{lll}
\hline Constraints & Mean score (x) & Decision \\
\hline Lack of market opportunity & 3.0 & Accepted \\
Lack of access to credit facility & 3.8 & Accepted \\
Lack of enabling environment & 3.5 & Accepted \\
Poor road network & 3.2 & Accepted \\
Poor market information & 2.8 & Accepted \\
Poor managerial skills & 2.6 & Accepted \\
Inadequate power supply & 2.7 & Accepted \\
Poor telecommunication facilities & 1.8 & Rejected \\
Inadequate information dissemination & 3.4 & Accepted \\
Lack of entrepreneurial skills & 2.3 & Rejected \\
Lack of entrepreneurship competency & 2.4 & Rejected \\
High taxation & 2.5 & Accepted \\
Poor government policies on entrepreneurial development & 3.6 & Accepted \\
Inability to withstand competition & 2.0 & Rejected \\
\hline SOure:
\end{tabular}

Source: Field Survey, 2012

From the analysis of the result in Table 4, it was observed that the acquisition of entrepreneurship skills among the farmers was constraints by lack of market opportunities (3.0), lack of access to credit facility (3.8), lack of enabling environment (3.5), poor road network (3.2), poor market information (2.8), poor managerial skills (2.6), inadequate power supply (2.7), inadequate information dissemination (3.4), high taxation (2.5) and poor government policies on entrepreneurial development (3.6). This finding conformed with the European Commission (1996) report that barriers to farmers' entrepreneurs' development to include: poor management skills of farmers, lack of entrepreneurial spirit, limited access to business support, farm tenancy agreements and regulation. They concluded that these barriers will differ for different farms depending on the personal and business characteristics of the individual farm and farmer. Similarly, Mandama (2010) reported that in Nigeria, lack of motivation, lack of finance, inadequate management skills, poor infrastructure, and taxation deter both youths and farming households from venturing into entrepreneurship world. Justifying inadequate credit facilities as a constraint to entrepreneurial development Duniya (2010), inferred that low productivity in agriculture has led to limited market surplus which prevents the prospective entrepreneurs in agriculture from having enough cash to procure farm input and services. Again, the formal financial intermediaries are not helping issues as most do refuse farmers from sourcing loan from their institutions due to lack of acceptable collateral, hence, branding the farmers as non-credit worthy.

\section{CONCLUSION AND RECOMMENDATION}

Based on the findings of this research, it was concluded that the farmers had been employing entrepreneurship skills in the farm and non-farm activities. This has lead to reduction of poverty among the farming household in the area. However, the extent of poverty reduction is still very insignificant, which is an indication that the farmers have not full taken advantage of some of the entrepreneurial activities or have participated to a less extent. In these categories is farm input supplies, which recorded very minimal farmers involvement. Hence, if the current transformation agenda of the present federal government on poverty eradication through farming activities must be actualized, there is urgent need to provide adequate entrepreneurship development programme for farmers while addressing factors that hinder the growth and development of farmers entrepreneur in the area.

\section{REFERENCES}

Duniya, A. S. (2010). Challenges of Entrepreneurship Development in Agriculture for Job Creation in Nigerian. Proceedings of the $24^{\text {th }}$ Annual National Conference of Farm Management Association of Nigeria held at Adamawa State University, Mubi between 11th $-14^{\text {th }}$ October, 2010. Pp. $1-4$. 
European Commission (2004). Com Green Paper Entrepreneurship in Europe. www.esofarmers.org.

Firlej, K. (2001). Rozwój przedsiębiorczości i tworzenie nowych miejsc pracy $w$ re-gionie małopolskim. Rozwój przedsiębiorczości wiejskiej w perspektywie inte-gracji z Unią Europejską: Międzynarodowa' ('Developing

entrepreneurship and new jobs in the region of southern Poland'). Konferencja Naukowa, Kraków, 11-12, stycznia 2001.

Knudson, W., Wysocki, A., Champagne, A. and Peterson, H. C. (2004). Entrepreneurship and Innovation in the Agri-food system. American Journal of Agricultural Economics. 86: 1330-1338.

Kudi, T. M., Usman, I., Akpoko, J. G and Banta, A. L. (2008). Analysis of the Impact of National Fadama Development Project II (NFDP II) in Alleviating Poverty Among Farmers in Giwa Local Government Area of Kaduna State, Nigeria. Ozean Journal of Applied Sciences. 1(1): 9 -15

Mandam, L. S. (2010). Entrepreneurship Development and Nigerian Transformation Process: Prospects and Challenges in Agriculture. Proceedings of the $24^{\text {th }}$ Annual National Conference of Farm Management Association of Nigeria held at Adamawa State University, Mubi between 11th $14^{\text {th }}$ October, 2010. Pp. ix - xii.

Mbam, B.N., Nwibo, S.U., and Odom, C.O. 2010. Rural Poverty and Reduction Strategies: A Case Study of Arochukwu Local Government Area of Abia State, Nigeria. African Journal of Professional Research in Human Development. De-Caritas Publishers Port Harcourt. 6(1): 45-52.

National Population Commission (NPC) (2006). Official Population Report of Igbo-Eze North Local Government Area of Enugu state.

Nwibo, S. U. and Okorie, A. (2013). Determinants of Entrepreneurship among Agribusiness Investors in South East, Nigeria. European Journal of Business and Management. 5(10): 115 - 123. Published by
International Institute for Science, Technology and Education, UK. ISSN 2222-1905 (Paper) ISSN $2222-2839$ (Online). Available online at: http://www.iiste.org

Ocar (2003). Fadama Development Project Appraisal report Agriculture and Rural Development, Department Central west region. Ocar 2 (Extension 2143).

Ogunlela, V. B. and Ogungbile, A. O. (2006). Alleviating Rural Poverty in Nigeria: A Challenge for the National Agricultural Research System. Available online@ @ww.

Oladimeji, I. O. (2004). Effect of World Bank loan withdrawal on the performance of agricultural extension in Nigeria. Nordic Journal of African Studies. 13(2): 141-145.

Vesala, K.M. and Peura, J. (2003). Farmers with Additional Business, Mono Active Farmers and Non-Farm Rural Small Business Owners in Comparison from the Viewpoint of Entrepreneurial Role Expectations. In Borch, O.J. and Ronning, L. (eds.) Entrepreneurship in Regional Food Production. Nordlandsforskning: NF-Rapport nr. 26/2003, Bodo, pp. 56- 82.

Warren, M. (2004). Farmers online: drivers and impediments in adoption of Internet in UK agricultural businesses. Journal of Small Business and Enterprise Development. 11(3): 371-381.

Youth Enterprise with Innovation in Nigeria (YouWiN) (2012). https://www.youwin.org.ng/index.php. accessed January 14th, 2013.

Żmija, J. (2001). Rozwój przedsiębiorczości w agrobiznesie w Małopolsce wobec integracji z Unią Europejską. Rozwój przedsiębiorczości wiejskiej w perspektywie integracji z Unią Europejską' ('Developing of entrepreneurship of agribusiness in Małopolska region before EU enlargement'). Międzynarodowa Konferencja Naukowa, Kraków, 11-12 stycznia 2001. 